\title{
COMPARISON OF ENERGY POTENTIAL OF THE EUCALYPTUS GLOBULUS AND THE EUCALYPTUS NITENS
}

\author{
S. Pérez, C. J. Renedo, A. Ortiz, M. Mañana, D. Silió, J Peredo \\ Department of Electric and Energy Engineering \\ ESTI Industriales y Telecomunicación, University of Cantabria \\ Av Los Castros s/n, 39005 Santander (Spain) \\ Phone: +34 942 201382, fax: +34 942 201385, e-mail: renedoc@unican.es
}

\begin{abstract}
In this work a power characterization of adult stages of the species Eucalyptus globulus and Eucalyptus nitens has been made.

The study has been made in six different plantations in Cantabria (North coast of Spain), located at a latitude $43^{\circ} 28^{\prime} \mathrm{N}$, and a longitude $3^{\circ} 48^{\prime} \mathrm{W}$. The region has approximately 30,000 Ha dedicated to the growth of Eucalyptus.

After the collection of samples they were weighed, analyzed and burned, resulting a mean net calorific value of $17,384 \mathrm{~kJ} / \mathrm{kg}$ and $17,927 \mathrm{~kJ} / \mathrm{kg}$ for the E. globulus and $\mathrm{E}$. nitens, respectively. Finally, the economic and environmental consequences that the crop of these species would suppose for the region of Cantabria were analyzed.
\end{abstract}

\section{Key words:}

Biomass, eucalyptus globulus, eucalyptus nitens, energy crops, forest wastes, net calorific value.

\section{Introduction}

Until the twentieth century the power sources that have been allowing the development of the humanity have been of fossil origin. Spain, like many others countries in the European Union, does not have great reserves of petroleum or natural gas, which means a need of external energy around the $75 \%$ of the total demand.

From our point of view, this situation justifies widely the study and development of alternative power plants whose raw material is a local resource. In this way, the power dependency would be reduced while the use of these energies will suppose a great environmental benefit.

Biomass is any substance of biological origin. The forest biomass is defined as the existing organic matter in a forest ecosystem, above and below the soil, although the useful one is only the superficial part. In the power sector, the biomass term is used when this is susceptible of being used like fuel.

The natural areas generate very significant environmental benefits (protection of the soil, fight against the erosion, defence against floods, carbon drain), economic goods (wood, firewoods) and other social and cultural services (tourism).

This way, apart of the decisive contribution to the environment protection, it supposes a considerable help to the socioeconomic development of rural areas, as much fixing population as generating alternative jobs.

In this article the biomass considered has forest origin, namely different species of Eucalyptus in the North of Spain, Cantabria.

\section{Forest biomasa in Cantabria}

The bioclimatic and geographic characteristics of this region form an optimal scenario for the development of forest species. The Cantabrian forests suppose more than $2 / 3$ of its territory, where almost $60 \%$ of them are in use. This supposes a great forest surface that is still susceptible of growing in an important way.

Table 1. Forest surface in Cantabria

\begin{tabular}{|c|c|}
\hline Use & Hectares $(\mathrm{Ha})$ \\
\hline Forest with trees & 209,611 \\
\hline Forest without trees & 145,201 \\
\hline Total forest & 359,458 \\
\hline Total Cantabria & 532,139 \\
\hline
\end{tabular}

The average wood generate annually in the area are $550,000 \mathrm{~m}^{3}$, where $93 \%$ correspond to Eucalyptus, $6 \%$ to Pine Radiate and $1 \%$ to other native species. These data reveal that the predominant production are species of fast growth, as it is the Eucalyptus.

Considering that 95,000 Tn of wastes are abandoned annually in the Cantabrian plantations, this amount justified widely the study made here, where the two more common species of Eucalyptus were characterized (globulus and nitens).

The biomass samples were collected in six plantations that were considered representative in the region, Fig. 1. 


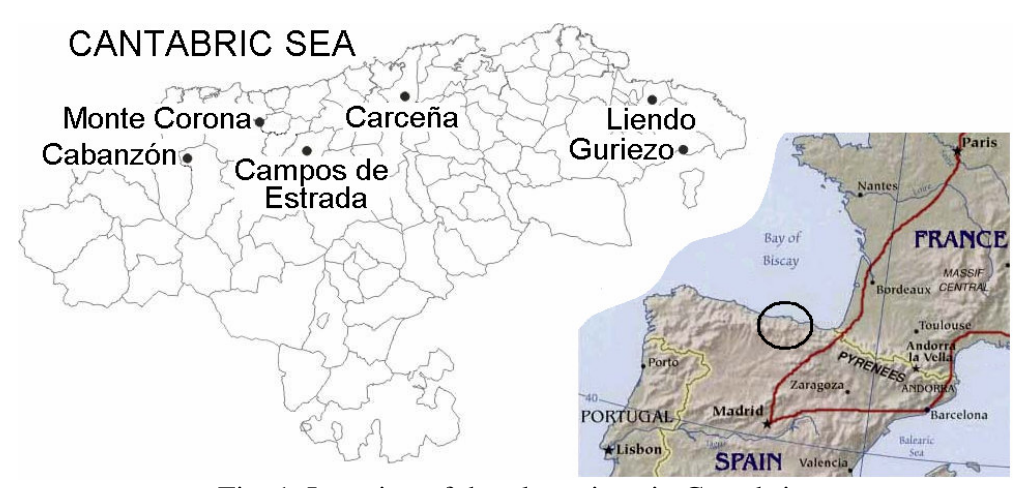

Fig. 1. Location of the plantations in Cantabria.

\section{Species considered}

The conventional use of the Eucalyptus is the paper industry, due to the high content in cellulose of its wood. In this sector the useful part is taken, leaving in the plantation the rest of the tree (bark, leaves, seeds, etc) like wastes.

The predominant species in the coastal zones is the E. globulus, whereas in the mountains or in zones with high probability of freezing, the typical species is the E. nitens. The latter is highly resistant to cold temperatures, however the cellulose production is lower than with $\mathrm{E}$. globulus.

Currently, the presence of insects plagues and fungi in the E. globulus, like gonipterus scutellatus, for the adult stage, and mycosphaerella molleriana, in youth, has caused that this species has lost importance in favour of the E. nitens, even in its natural area of development, which are the coastal zones.

\section{Calorific value and water}

The parameter most important to characterize a substance as combustible is the calorific value. This is defined as the amount of heat that gives when it is burned, with excess of oxygen, to a given pressure and temperature.

Two calorific values are defined:

- Gross calorific value (GCV), assuming that the water generated in the combustion is in steam state.

- Net calorific value (NCV), if the water generated in the combustion is in liquid state.

The method used gives like result the GCV, the difference between both is the vaporization energy of the water in the products of the combustion. This water is provided by the air humidity, the biomass humidity and hydrogen contained in the dry waste. The relation between the GCV and the $\mathrm{NCV}$, considering that the vaporization heat of water is $2,442 \mathrm{~kJ} / \mathrm{kg}$, can be expressed like in Eq (1):

$\mathrm{NCV}=\mathrm{GCV}-2,442\left[0.01\left(\mathrm{H}_{\mathrm{b}}-\mathrm{H}_{\mathrm{a}}\right)+0.09 \mathrm{H}_{\mathrm{d}}\right](1)$ where $\mathrm{Hd}$ is $\%$ of hydrogen in the dry sample, $\mathrm{Hb}$ is $\%$ of humidity in the waste and $\mathrm{Ha}$ is \% of air humidity in the combustion.

The NCV is most relevant at the time of characterizing a fuel, since it is the one that usually is used in a combustion. The determination of the NCV, is not only fundamental at the time of evaluating a substance from a power point of view, but also gives an idea of its inflammability or its potential to generate and to propagate fires. Another important variable in the power study of these wastes is the humidity content. This parameter not only varies with the season of the year in which the sample is collected, but also varies with time between the tree is cut until it is burned.

\section{Experimental}

The first stage of the work on the field was to determine where to collect the samples and which size should them have to get realistic conclusions.

In this point it is necessary to thank the company Bosques 2000 S.L. (Sniace Group), owner of 5,500 Has of Eucalyptus plantations in Cantabria, for his help.

Three zones of each species were chosen to make the study. The plantantions were located in the Eastern, Central and Western part of the region, in such a way that the biomass samples were representative enough, Fig. 1.

Once inside each chosen zone, the samples were collected avoiding low or high densities of trees, irregular surfaces, edge effects or any singular characteristic that differs from a normal individual.

The plantations also were characterized by the type of soil, the solar radiation, topography, structure, fertilization programs, etc.

All these variables influence consequently the volume and the quality of the wood and wastes.

The samples of E. globulus were collected at altitudes below 250 metres, whereas the samples of E. nitens were found between 250 and 500 metres. 
The forest wastes are obtained from several parts of the tree, leaves, think branches $(3 \mathrm{~cm}<$ diameter $<7 \mathrm{~cm})$, thin branches (diameter $<3 \mathrm{~cm}$ ), seeds and bark.

From each selected area, two trees were cut and next several samples of each part that compose the wastes were extracted.

Once the samples were collected and classified, they were transported to the Energy Laboratory of the University of Cantabria, where they were weighed and burned with different humidity degrees.

From each sample, approximately 1 gr fraction was extracted (humidity included). A part of it was destined to analyze the humidity degree, and the other was burned in a calorimeter to evaluate its potential energy.

The material used in the laboratory for the characterization of the wastes consisted of a humidity analyzer, a precision balance, and a calorimeter. The humidity analyzer is electronic, model MA145 Sartorius, and allows to measure the humidity of the different parts that compose the wastes, with a sensitivity of $0.01 \%$. Its operation principle of this based on the method of thermogravimetry. So, first the sample is weighed and later is dried, being a destructive trial.

The samples analyzed in the calorimeter were previously weighed with a balance whose sensibility is $0.1 \mathrm{mgr}$, model BP 121S of Sartorius.

The combustion experiments have been made in a calorimeter, model C 5000 IKA. This calorimeter is able to analyze combustible in liquid or solid form, making the combustion in an atmosphere of $\mathrm{O}_{2}(99.99995 \%$ pure, provided by Air Liquide, Spain), which assures the complete combustion of the sample.

The calorimeter allows two operation ways, one adiabatic (without thermal losses), according to the standard DIN, and another isoperibolic (constant reference temperature), according to the standard ASTM.

The water produced by the combustion is in liquid state, therefore, the calorimeter gives the GCV.

\section{Results}

The influence of physical and geographic parameters in the power values is negligible. For this reason, only the average values of the six plantations are presented.

Table 2. Average GCV (kJ/kg)

\begin{tabular}{|c|c|c|}
\cline { 2 - 3 } \multicolumn{1}{c|}{} & E. globulus & E. nitens \\
\hline Leaves & 12,848 & 17,033 \\
\hline Thick branches & 7,829 & 9,013 \\
\hline Thin branches & 7,621 & 12,105 \\
\hline Bark & 5,908 & 7,010 \\
\hline Seeds & 11,564 & 11,150 \\
\hline
\end{tabular}

In Table 2 the average values of the GCV, for all the samples of the species studied, to maximum humidity (after the collection), is presented.

In Figs. 2 and 3, the averages of the GCV and NCV resulting from the different parts that compose the wastes are showed.

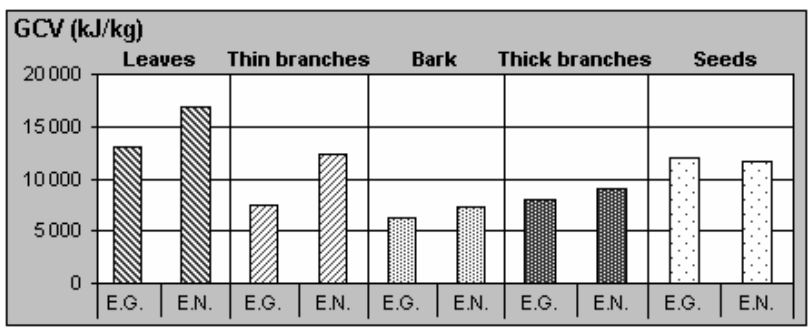

Fig. 2. Comparison of the GCV resulting from the different parts that compose the waste

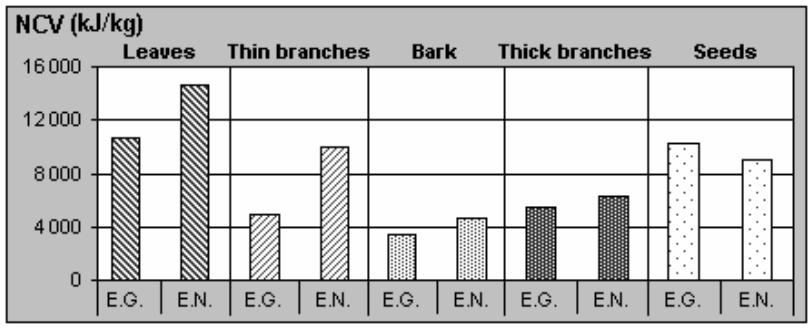

Fig. 3. Comparison of the NCV resulting from the different parts that compose the waste

Regarding the results, it is observed that the greater values of specific energy are obtained from the leaves and the seeds, being the lower ones those corresponding to the bark.

Perhaps the fact more remarkable of this research is that the E. nitens gives more power than the E. globulus which happens in all the types of wastes except in seeds.

This is justified because the E. nitens, in the adult stage, has a greater concentration of volatile components and essential oils, than the E. globules. These substances have GCV superior to $40,000 \mathrm{~kJ} / \mathrm{kg}$, which is very important for the GCV of the wastes.

The fraction, in weight, of each component of the tree, is indicated in Table 3. The greater fraction corresponds to useful wood, being the total wastes left in the plantations $20 \%$ of the weight of the tree. In fig 4 , the average values of the wastes have been represented, considering the percentage of each part of the tree indicated in Table 3.

Table 3. Percentage, in weight, of each part of the tree (\%)

\begin{tabular}{|l|c|c|}
\cline { 2 - 3 } \multicolumn{1}{c|}{} & E. globulus & E. nitens \\
\hline Leaves & 6,9 & 6.7 \\
\hline Branches & 8.7 & 9.3 \\
\hline Bark & 11.5 & 11.3 \\
\hline Seeds & 0.9 & 0.3 \\
\hline Wood & 72 & 72.4 \\
\hline
\end{tabular}


Table 4. Average of the elementary chemical composition of the samples of E. globulus and E. nitens

\begin{tabular}{|c|c|c|c|c|c|c|}
\cline { 3 - 6 } \multicolumn{2}{c|}{} & $\mathrm{H}$ & $\mathrm{C}$ & $\mathrm{N}$ & $\mathrm{S}$ & O (by diff.) \\
\hline \multirow{4}{*}{ E. globulus } & Leaves & 7.27 & 54.01 & 1.41 & 0.22 & 37.09 \\
\cline { 2 - 7 } & Think branches & 6.98 & 46.01 & 0.75 & 0.13 & 46.13 \\
\cline { 2 - 7 } & Bark & 6.60 & 49.92 & 0.65 & 0.20 & 42.63 \\
\cline { 2 - 7 } & Thin branches & 7.13 & 50.09 & 0.54 & 0.09 & 42.15 \\
\cline { 2 - 7 } & Seeds & 7.11 & 44.91 & 1.21 & 0.11 & 46.66 \\
\hline \multirow{5}{*}{ E. nitens } & Leaves & 7.12 & 56.89 & 1.31 & 0.16 & 34.52 \\
\cline { 2 - 7 } & Think branches & 6.78 & 48.16 & 0.78 & 0.21 & 44.07 \\
\cline { 2 - 7 } & Bark & 7.22 & 57.31 & 0.71 & 0.14 & 34.62 \\
\cline { 2 - 7 } & Thin branches & 6.85 & 53.24 & 0.68 & 0.25 & 38.98 \\
\cline { 2 - 7 } & Seeds & 6.92 & 45.03 & 1.06 & 0.09 & 46.9 \\
\hline
\end{tabular}

Table 5. Annual economic evaluation per Ha

\begin{tabular}{|c|c|c|c|c|c|c|c|}
\cline { 2 - 8 } \multicolumn{1}{c|}{} & $\begin{array}{c}\text { Wastes } \\
\text { (kg/ Ha year })\end{array}$ & $\begin{array}{c}\text { NCV } \\
(\mathrm{kJ} / \mathrm{kg})\end{array}$ & $\begin{array}{c}\text { Electric Efficiency } \\
(\%)\end{array}$ & $\begin{array}{c}\text { Electricity } \\
(\mathrm{kWh} / \text { Ha year })\end{array}$ & c€/kWh & $€ /$ Ha year & $\mathrm{M} € /$ year \\
\hline E. globulus & 5,702 & 5,478 & 20 & $1,735.3$ & \multirow{2}{*}{6.7} & 116.3 & 2.75 \\
\hline E. nitens & 6,624 & 7,289 & & $2,682.3$ & & 179.7 & 1.06 \\
\hline
\end{tabular}

Table 6. Annual environmental analysis per Ha

\begin{tabular}{|c|c|c|c|c|c|c|c|c|c|c|}
\cline { 2 - 10 } \multicolumn{1}{c|}{} & $\begin{array}{c}\text { Word } \\
\left(\mathrm{m}^{3}\right)\end{array}$ & $\begin{array}{c}\text { Density } \\
\left(\mathrm{kg} / \mathrm{m}^{3}\right)\end{array}$ & $\begin{array}{c}\text { Wood } \\
(\mathrm{kg})\end{array}$ & $\begin{array}{c}\text { Wastes } \\
(\mathrm{kg})\end{array}$ & $\begin{array}{c}\text { \% } \mathrm{C} \text { in } \\
\text { wood }\end{array}$ & $\begin{array}{c}\% \mathrm{C} \text { in } \\
\text { wastes }\end{array}$ & $\begin{array}{c}\mathrm{C} \text { in wood } \\
(\mathrm{kg})\end{array}$ & $\begin{array}{c}\mathrm{C} \text { in wastes } \\
(\mathrm{kg})\end{array}$ & $\begin{array}{c}\mathrm{C} \text { total } \\
(\mathrm{kg})\end{array}$ & $\begin{array}{c}\text { Fixed } \mathrm{CO}_{2} \\
(\mathrm{~kg} / \mathrm{Ha} \mathrm{year})\end{array}$ \\
\hline E. globulus & 32 & 785 & 25,120 & 5,869 & 52.80 & 49.42 & 13,263 & 2,900 & 16,164 & 64,656 \\
\hline E. nitens & 37 & 696 & 25,752 & 6,563 & 53.12 & 50.99 & 13,679 & 3,346 & 17,026 & 68,105 \\
\hline
\end{tabular}

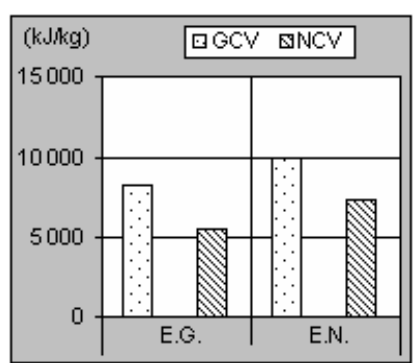

Fig. 4. Comparison of the average calorific value of the two species.

From the power point of view of the energy obtained, the wastes of E. nitens are superior to those of E. globulus. Nevertheless, from the wood industry perspective, is the E. globulus the one that presents greater interest, due to its high content in alphacelluloses.

In Table 4, the elementary chemical analysis of the different parts that compose the wastes, for both species in the two stages of growth studied it is shown.

Because the fertilization programs used in the plantations selected were similar, small variations are observed. Perhaps, in plantations without fertilization, the percentage are more variable, specially in the percentage of nitrogen and sulfur.

Assuming an average wood production per Ha and year like one indicated in Table 5, a yield in the electrical generation of $20 \%$, and a electricity price of $6.7 \mathrm{c} € / \mathrm{kWh}$, it is possible to estimate the production of the region of Cantabria, and what would suppose economically the collection of these wastes. For this, the total surface dedicated to the growth of E. nitens, 5,906 Ha, and E. globulus, 23,610 Ha, have been considered.

From the environmental point of view, the benefits that would provide the average production previously described, in tons of $\mathrm{CO}_{2}$ fixed per $\mathrm{Ha}$ and year, has been calculated. The results reveal that these type of plantations are real carbon drains, Table 6.

\section{Conclusions}

In Cantabria the use of the forest wastes of E. globulus and E. nitens for the electrical generation, would suppose an approximate energy of $57 \mathrm{GWh}$. This could produce an annual income of 3,8 $\mathrm{M} €$, since this type of energy is considered within an special regime.

From the power point of view, the wastes of the E. nitens are better than those of the E. globulus, and this happens in spite of the greater commercial interest of the $E$. globulus, for the paper industry.

The data of the work can be exportable to other places with similar bioclimatic characteristics, in which these species exist, since the influence of the type of soil and orientation of the plantations has not been relevant in the cases considered. 
Finally, the environmental balance has been presented. The $\mathrm{CO}_{2}$ fixed by this type of plantations is determined, being an interesting economic alternative for the Market on Carbon Emissions, which is a mechanism anticipated by the Protocol of Kyoto.

\section{Acknowledgments}

The authors want to thank to the Council on Research and Technological Development of the University of Cantabria by their financial support, to the company Bosques 2000 S.L. for his great help and to the Forest Department of the Government of Cantabria by its support in the collection of samples and data.

\section{References}

[1] http://www.idae.es.

[2] B. Kjellén. Conferencia sobre cambios climáticosimplicaciones y consecuencias. Valencia. September 2001.

[3] P. del Río, F. Hernández, M. Gual. Energy police 33 (2005) 2010-2022.

[4] K. Pingoud, A. Lehtilä and I. Savolainen. Environmental Science \& Police 2 (1999) 153-163.

[5] M. Balat, Biomass and bioenergy, 29 (2005) 22-31.

[6] S. Perez, C.J. Renedo, D. Silió, A. Ortiz, M. Mañana, ICREPQ'05, Zaragoza Spain (2005).

[7] Plan Forestal de Cantabria, Gobierno de Cantabria. Dirección General de Montes y Conservación de la Naturaleza. 2004

[8] $3^{\circ}$ Inventario Forestal. Gobierno de Cantabria. Dirección General de Montes y Conservación de la Naturaleza. 2004

[9] http://www.uhu.es/cideu.

[10] M. Balboa, J. Alvarez. Cis-madera, (2003) 27-37.
[11] E. Ralfh, H. Sims, Kingiri Senelwa, et al. Biomass and Bioenergy, 16 (1999) 199-205.

[12] S. Santolamazza-Carbone, A. Rodríguez-Illamola, and A. Cordero, Biological Control 29 (2004) 24-33.

[13] A.R. Clarke, S. Paterson, P. Pennington, Forest Ecology and Management 110 (1998) 89-99.

[14] Abbott, P. Van Heurck, T. Burbidge and M. Williams, Forest Ecology and Management 58 (1993) 85110.

[15] L Guo, R. Sims, D. Horne,, Bioresource Thechnology 85 (2002), 273-283.

[16] M. Moran, H. Shapiro. Termodinámica Técnica. Ed Reverté 2004.

[17] L. Baxter et al. Dev. Thermochem. Biomass Conwers. (1997), 2, 1278-1292.

[18] www.sniace.com.

[19] M. Battaglia, P. J. Sands, S. G. Candy. Forest Ecology and Management. 120 (1999) 193-201.

[20] R. K. Mistra, C. R. A. Turnbull, R. N. Cromer, A. K. Gibbons, A.V. LaSala. Forest Ecology and Management. 106 (1998) 283-293.

[21] J. L. Montero, J. L. Gonzalez, Diagramas Bioclimáticos, ICONA, Ministerio de Agricultura, Pesca y Alimentación, 2002.

[22] K. Senelwa, R. Sims, Biomass and Bioenergy, 17 (1999, 127-140).

[23] E. Martín, F Lara, Inflamabilidad y energía de las especies del sotobosque, Ed Instituto Nacional de Investigaciones Agrarias, Ministerio de Agricultura, Pesca y Alimentación, 1989.

[24] Bosques 2000 S.L. Departamento de Investigación y Desarrollo (Internal data).

[25] S. Pérez, C.J. Renedo, D. Silió, A. Ortiz, M. Mañana, IV Jornadas Nacionales de Ingeniería Termodinámica, Logroño 2005.

[26] http://www.ree.es. 